\title{
DITERPENE ALKALOID KARACOLINE FROM Taxus baccata GROWING IN GEORGIA
}

\author{
L. G. Kintsurashvili
}

UDC 547.945/944

The plant Taxus baccata L. (Taxaceae) is known as a source of the alkaloid taxol, which exhibits antitumor properties [1]. It is broadly distributed in the western regions of Georgia.

The in vitro pharmacological activity of the alkaloid fraction enriched in taxol that was obtained by us from the aerial parts of T. baccata was studied in various dilutions for cultured tumor cells A-549 (lung carcinoma), DLD-1 (rectal adenocarcinoma), and WS-1 (fibroblastoma) in the Basic Sciences Department, University of Quebec in Chicoutimi, Canada. Inhibition by $50 \%$ was demonstrated for cultured tumor cells A-549, DLD-1, and WS-1 at dilutions $18.5 \pm 0.8 \mu \mathrm{g} / \mathrm{mL}$ and $8 \pm 1 \mu \mathrm{g} / \mathrm{mL}$ (A-549), $58 \pm 10 \mu \mathrm{g} / \mathrm{mL}$ and $15 \pm 2 \mu \mathrm{g} / \mathrm{mL}$ (DLD-1), and $36 \pm 7 \mu \mathrm{g} / \mathrm{mL}$ (WS-1) [2].

The goal of our investigation was to study further the chemistry of the alkaloid-containing fraction isolated by us.

Analysis of this fraction showed that taxol was accompanied by an alkaloid that had the same mobility as an analogous component in the commercial preparation. Separation over a column of silica gel with elution by $\mathrm{CHCl}_{3}$ and $\mathrm{CHCl}_{3}: \mathrm{MeOH}$ $(1-20 \%)$ isolated crystalline base $\mathrm{A}_{3}$, mp $185-187^{\circ} \mathrm{C}\left(\mathrm{CHCl}_{3}: \mathrm{MeOH}\right)$.

The base isolated by us was identified based on spectral data (PMR and ${ }^{13} \mathrm{C}$ NMR) and comparison with the literature as the known alkaloid karacoline, which was obtained previously from Aconitum karacolicum [3, 4].

PMR spectrum $\left(\mathrm{CDCl}_{3}, \delta, \mathrm{ppm}\right): 0.85\left(3 \mathrm{H}, \mathrm{s}, \mathrm{N}-\mathrm{CH}_{2}-\mathrm{CH}_{3}\right), 1.055\left(3 \mathrm{H}, \mathrm{m}, \mathrm{N}-\mathrm{CH}_{2}-\mathrm{CH}_{3}\right), 3.5\left(3 \mathrm{H}, \mathrm{s}, 16-\mathrm{OCH}_{3}\right), 4.0$ (1H, m, H-14). ${ }^{13} \mathrm{C}$ NMR spectrum $\left(\mathrm{CDCl}_{3}, \delta\right.$, ppm): 71.480 (C-1), 29.373 (C-2), 31.298 (C-3), 32.317 (C-4), 46.072 (C-5), 24.950 (C-6), 44.539 (C-7), 73.385 (C-8), 46.109 (C-9), 39.993 (C-10), 48.475 (C-11), 29.445 (C-12), 43.828 (C-13), 74.485 (C-14), 41.789 (C-15), 82.388 (C-16), 61.955 (C-17), 27.099 (C-18), 59.650 (C-19), $12.595\left(\mathrm{~N}-\mathrm{CH}_{2}-\mathrm{CH}_{3}\right)$.

The diterpene alkaloid karacoline was isolated for the first time from T. baccata.

We also studied the accumulation dynamics of the taxol fraction according to vegetation phases of $T$. baccata collected in various habitats:

$\begin{array}{ccc}\text { Collection site } & \text { Content of pharmacologically active taxol fraction, } \% \\ & \text { Flowering } & \text { Fruiting } \\ \text { Tskhaltubo } & 0.036 & 0.031 \\ \text { Terjola } & 0.042 & 0.033 \\ \text { Tbilisi (botanical garden) } & 0.010 & 0.009\end{array}$

It can be seen from the results that the maximum accumulation of the pharmacologically active taxol fraction occurred during flowering in the plant growing in the vicinity of Terjola.

\section{REFERENCES}

1. L. G. Kintsurashvili and V. Yu. Vachnadze, Georgian Chem. J., 4, No. 2, 155 (2004).

2. L. G. Kintsurashvili, in: Abstracts of Papers of the Ind International Scientific Conference "Chemistry, Technology, and Medical Aspects of Natural Compounds" [in Russian], Alma-Aty, Oct. 10-13, 2007, p. 193.

3. M. N. Sultankhodzhaev, M. S. Yunusov, and S. Yu. Yunusov, Khim. Prir. Soedin., 399 (1971).

4. S. Yu. Yunusov, Alkaloids [in Russian], Fan, Tashkent, 1981, p. 91.

I. G. Kutateladze Institute of Pharmaceutical Chemistry, Tbilisi State Medical University, Georgia, Tbilisi, P. Saradzhishvili, 36, fax: (99532) 5200 23, e-mail: farm_alkaloids@yahoo.com. Translated from Khimiya Prirodnykh Soedinenii, No. 1, January-February, 2013, p. 157. Original article submitted July 28, 2011. 